\title{
The Un-Trollopian Trollope: Some Notes on the Barsetshire Novels
}

Miguel Ángel Pérez Pérez Universidad de Alicante

\begin{abstract}
The six Barsetshire novels are not only Anthony Trollope's most popular ones, but also those which are usually considered to represent the author at his mildest and most conventional, as regards the Victorian social and ethical codes. Without entirely disregarding this view, this paper argues that Trollope disguises many of his own opinions behind an apparently unproblematic presentation of characters, situations and attitudes. The essay is therefore an attempt to delineate some of these techniques of "concealment", with the aim of exposing some of the double readings discoverable in Trollope's novels.
\end{abstract}

Anthony Trollope's best known series of novels, the Barsetshire group, are a gentle portrait of a very specific rural society in mid-nineteenth-century Victorian England which receives frequent-and sometimes threatening-visitors from London. This mixture of two worlds allows for a wide canvas of characters who interact on both a social and an economic basis, thus giving place to a number of - again - very specific conflicts. So we get amorous relationships, social and religious disputes, economic problems and moral dilemmas, all of which account for the subject-matter of each of the narratives. Consequently, we can say that everything that might be expected at the basis of this type of realistic constructions is present in Trollope's tales: the emotional evolution of the characters as members of a society characterized by certain strict patterns of behaviour and by an economic structure which rules their existence and makes the English class system possible; the presentation, development and solution of 
a number of conflicts which affect these characters, considered from the point of view of the moral values shared by both author and readers and which is proper to Trollope's historical period; the writer's ability to structure these conflicts in a way that enables him to arouse his readers' interest and expectations ${ }^{1}$; and finally, the pervasive presence of an omniscient narrator who makes frequent incursions that interrupt the telling of the story itself so that this voice may directly address the reader, following the line initiated by Fielding's self-reflexive style.

To sum up, Trollope may be defined initially as just another Victorian novelist with a very clear and definite approach as to what a story should be about and how it should be narrated. Obviously this implies that Trollope's literary achievement and his position in the traditional canon depend directly on his ability to handle the tools enumerated above. In this line of thought, Walter Allen's words provide a good summary of Trollope's accomplishments and limitations and set out an accurate pattern that will enable us to analyze his books:

He knew exactly what the novel should be; it was what the majority of readers have always wanted it to be: "a picture of common life enlivened by humour and sweetened by pathos". His failings are obvious. His style is commonplace, so that he relies wholly on the interest of his subject-matter; when the subject-matter is dull Trollope is dull. He has no sense of form: he was content to produce a story that would, somehow, fill three volumes of a novel, a novel, moreover, that was to appear as a magazine serial before publication. As he realized himself, he had little skill in plot construction, which was both an asset to him and a liability. Everything conspired to make him a superb improvisator; one reads him from chapter to chapter, with little sense of the whole. ${ }^{2}$

Allen is right, and this is certainly a reliable general description of Trollope's working method and results. But there is something else in Trollope's priorities and limitations when he is embarking on the creation of a novel, something that partly escapes these rather trite generalities and offers us a far more interesting facet of the novelist's mind, even though a conventional reading of his books is interesting in itself. On the one hand, Allen speaks of prolixity, improvisation and problems of construction. This is interesting since it allows us to wonder how often Trollope is really improvising in the hurry to finish a chapter or a certain episode in his story, and how much second thought there is behind his arranging of words $s^{3}$. On the other hand - and this is my main point here - when we read Trollope's novels we often wonder to what degree he is sincere in his rendering of that "picture of common life". This rather dangerous term "sincerity" means here the extent to which the narrator really wants us to believe in what he is telling us, and if it were not so, then we should decipher which is the real vision of the author regarding his characters and what it is that we are supposed to understand ${ }^{4}$.

Of course I do not claim that my conception of the Trollopian universe is at all new. In fact, I propose in the main to follow the path established by A.O.J. Cockshut in his now classic study on Trollope. But in the Preface to his book Cockshut dismisses the Barsetshire novels as too mild and irrelevant to his point: 
[...] it is part of my thesis that Trollope is a gloomier, more introspective, more satirical and more profound writer than he is usually credited with being; and further, the Barsetshire series, fine as it is, is not fully characteristic of his genius. Again, this series, so rich in incident and character, is simple in conception. ${ }^{5}$

While sharing Cockshut's view of the true nature of Trollope as a writer, I also think that the Barsetshire novels are not so simple in conception, since they allow for different readings as far as some of their characters are concerned. Trollope is certainly more pessimistic in his conception of human nature than a literal reading of any of these novels seems to imply, but this is so because he arranges his characters' actions and even thoughts in an ambiguous way that never reveals his position in relation to them, no matter how often his omniscient narrator may intrude upon the story with some sort of commentary. Thus he can please his readers without the risk of exposing himself in his views of humanity and the Victorian society he belonged to. Certainly he can make fun of the clergy in the Barsetshire novels in a much milder, amusing and even (to his contemporaries) acceptable way than that in which he savagely attacks certain examples of moral decadence in later books such as The Way We Live Now; but nevertheless his gloomy basis was there from the very beginning.

A character such as the famous Mrs Proudie may provide a good example of Trollope's ambiguity in the rendering of his characters. It is standard practice by now to mention the satirical component in his novels, which gives them that necessary and supposedly pleasant humour so essential to the writer's conception of what a novel should be, as well as being another inherited Augustan weapon by means of which he can criticize certain attitudes and modes of behaviour from the perspective of that shared morality ${ }^{6}$. Mrs Proudie contributes with both sides of the same coin, since she provides us with some of the funniest episodes in the novels (especially in Barchester Towers) through her intransigent and crushing personality while, at the same time, being an easy prey to our moral disgust. Once again, the basis for the interpretation of the character is the ethical conception of the world shared by both author and readers. From this point of view, Mrs Proudie represents certain negative features which Trollope readily marks so as to entertain the reader, while at the same time making true Swift's definition of satire, according to which the reader will smile when contemplating such a portrait as Mrs Proudie's in the distorting mirror but will never see himself reflected in it. Since we are indulging in terminologies, we might as well add that Mrs Proudie is a "bore" in the same style as those who abound in the novels of Jane Austen, a writer from whom Trollope learnt how to create such characters so that they are never "ffat", but from whom he is quite a distance apart in the limited subtlety with which he delineates a character such as the bishop's wife, if we take the character simply as she is presented to us in the books. Austen's apparently inoffensive characters can be far more menacing than this agitated woman who from her episcopal palace is capable of destroying lives for the sake of the eternal salvation of her brethren.

However, there is something else in a character like Mrs Proudie which adds a new dimension to her satirical features. To understand this, we have to rely - pace Northorp Frye- on Trollope, whose Autobiography is at times a very useful tool in order to get a 
clearer picture of his way of thinking and, consequently, of his writing (though, of course, I would not like to sound so naive as to be eager to believe literally in everything Trollope says in it). After reminding us of the most outstanding negative aspects of Mrs Proudie, Trollope goes on to say of her that

[...] at the same time she was conscientious, by no means a hypocrite, really believing in the brimstone which she threatened and anxious to save the souls around her from its horrors. And as her tyranny increased so did the bitterness of the moments of her repentance increase in that she knew herself to be a tyrant, - -till that bitterness killed her. ${ }^{7}$

Thus all of a sudden Mrs Proudie acquires the full weight and consistency of a human being thanks to her creator's sort of defence, instead of being just an exaggerated comical character of the "Iarger-than-life" kind. Satirical characters can never be so self-conscious. But we find such a statement on Mrs Proudie in Trollope's memoir, not in any of the novels. In these, Trollope's narrator never tells us anything like this about her, nor can we infer anything like it from the way in which her actions and thoughts are told ${ }^{8}$. We certainly see her in fear of her husband at the end of Barchester Towers, and then feeling remorse in The Last Chronicle of Barset, but the first scene is just an excuse for Trollope to finish his novel properly, and the second happens just before Mrs Proudie's unexpected death. For the rest, this woman is shown to us as possessing certain human characteristics in her capacity as a satirical figure, but not as a human being (and, as Trollope was well aware, satire taken to an excessive limit annihilates any trace of real humanity in a character). Such an omission, therefore, implies some sort of deceit. Now, with these comments on Mrs Proudie Trollope does not just give us a satirical portrait of a certain type of person, but acknowledges the fact that such people do exist, and that their acts and motivations may be as legitimate as those of the characters we consider to be the positive ones. Behind Mrs Proudie's comical function or faÇade we find the author's veiled assumption that the world can be darker than what the generically happy endings of his novels - to each what he or she deserves according to the ruling code- seem to indicate. So Trollope is subtle for once, so to speak, and as against a Dickens who overwhelms us with his resounding prose and makes us face the "truths" of life, Trollope just lets us read between the lines (almost against his own wishes, we might say) and glimpse the possibility that perbaps "common life" is not exactly the same as that which he narrates in his books. After all, by making Mrs Proudie a leading comic character, Trollope is "sweetening" his "picture", since he provides us with a satirical basis from which to judge this character. We should not forget that, as Allen wrote, a novel by Trollope was "what the majority of readers have always wanted it to be". And this does not mean that the general public's tastes and the writer's vision of life have to coincide. Oddly enough, Trollope's realism suddenly becomes a disguise.

A disguise for what? At the beginning of his Autobiography Trollope the prolific or rather, Trollope the novelist for whom the delineation of character was more important than that of plot - states "that I, or any man, should tell everything of himself, I hold to be impossible" (7). In The Last Chronicle of Barset, Mrs Dale asks: "Who can look into 
a man's heart and judge all the sources of his actions?"10 In many instances of the characteristically long meditations of his characters, written in free indirect style, it is quite clear that they do not tell all the truth about themselves, but are often quite partial and incomplete in their reasonings, to the narrator's mute relish. If we dare go one step further, we might say that there are also occasions when these characters' factotum, our author, does not say or accept or make explicit the whole truth about his creatures either. Trollope attributed his success as a novelist mainly to his ability to create "real" characters, to his acute portrayal of the different sides of their personalities, to his living with them for a long time and getting to know them intimately ${ }^{11}$. But this does not imply that he is obliged to tell us the whole truth about them. There is a realistic and conventional Trollope, amply satisfying as such, and also another one who will not tell us all that he knows about his characters, or who does not dare tell us everything, or who gives us a milder picture of what these characters are meant to be, or who is simply not fully aware that he is negating, in this subtle and indirect way, that fragment of reality which he chooses as the starting point for his narration. There is an anti-Trollope who is indivisible from the writer who responds to all the main features proper to his age, from that conventional and narrowsighted Victorian author who provoked Auden and Isherwood's relative shock when they read Framley Parsonage, an archetypal "English" novel, in their 1938 journey towards the heart of a remote war in Manchuria.

Lily Dale, one of Trollope's best known heroines, is another case in point, since she provides us with some ambiguities as to the way in which we should understand her. At any moment in Trollope's stories we find passages of an apparently neutral nature, the interpretation of which can be rather tricky. In the initial chapters of The Small House at Allington we find a good example of this. We are present at the first stages of the romance between Lily Dale and Adolphus Crosbie in a bucolic - and satiricalscene in which both characters, in the company of Lily's sister and their cousin, start getting to know one another. Lily, the main female character in the book around whom most of the action revolves, dominates the episode in the same way as she dominates her small kingdom, that equally small house in which Crosbie's irruption already seems to be on the point of occupying an important place ("Lily, though she was still queen of the croquet ground, had to acknowledge a male sovereign in that dominion"12). But there is a brisk transition at the end of this chapter, when the narrator focuses on the quiet presence of Bell, Lily's sister, and we read the following:

And so they all became very intimate; while Bell sat quietly under the tree, listening to a word or two now and then as Mr Crosbie chose to speak them. There is a kind of enjoyment to be had in society, in which very few words are necessary. Bell was less vivacious than her sister Lily; and when, an hour after this, she was dressing herself for dinner, she acknowledged that she had passed a pleasant afternoon, though $\mathrm{Mr}$ Crosbie had not said very much. (23) 
Nothing in the previous development of the story might have made us foresee this ending. On the contrary, we would rather have expected to be given a description of Lily's thoughts, not of her sister's. Why, then, does Trollope choose to present it in this way? To make clear the differences in thinking and behaviour between the two girls? As a way of hinting at the possibility of a future amorous interest in Crosbie on Bell's part, a path that later on the plot will not follow? Or simply because the hurried Trollope had to finish his chapter in some way? All these possibilities are quite plausible, but let us concentrate on the first one. Bell will move on to occupy a passive and definitely secondary role in the story that will culminate in her conventional marriage to her fiancé, and we shall rarely be given again a direct exposition of her thoughts. So these lines do not seem to have a very significant function, unless the writer's aim is to express, somewhat indirectly, that his heroine Lily Dale's actions and thoughts require a reading between the lines, since he is not going to be the one who will openly criticise her ways. Thus the emphasis on this apparently unimportant and inoffensive meditation of Bell's may suggest that Trollope's sympathies fall on her side, a nice simple girl for whom there has simply been an entertaining social intercourse on the lawn, rather than on Lily's, who is right now starting her masochistic via dolorosa, dominated by her infatuation and for which she is just as responsible as the official villain, Crosbie, who will jilt her in order to marry a lord's daughter and gain the social advantages this implies. Trollope seems to suggest as early as this point of the novel that it would be much better for Lily to be like her sister, in the face of the events to come. He is not attacking or satirizing or even commenting on Bell's passivity or lack of vivacity, but Lily's excess of it.

Most of the female characters in Trollope's books are characterized by their submission and lack of individuality. Lily breaks this pattern to a certain degree through the exacerbation of her idiosyncrasies both in this book and in The Last Chronicle of Barset, and this has brought her the status of an admirable heroine, capable of the deepest unrewarded love and unmoved by the social pressure around her that demands her marriage - her regeneration - to the utterly conventional Johnny Eames ${ }^{13}$. But Trollope's interest lies in a different direction. One can feel the gusto with which he takes Lily out of her small kingdom in Allington, where she has sufficiently tyrannised over her mother and uncle, and puts her to the test in London, not a land of promise here but rather one of temptation. In this way the author will have the opportunity to bring her and Crosbie together in a number of chance encounters, and thus please his readers with the sensation of such occasions and the expectancy of whatever may happen. But this change of scenery also allows him to diminish the glamour of his heroine, and show her as more what she really is when away from her throne. Of course Lily is no fool, and she has certain moments of sincerity, as when in The Last Chronicle of Barset she acknowledges the real nature of her obsessive passion for Crosbie:

I cannot define what it is to love him. I want nothing from him - nothing, nothing. But I move about through my little world thinking of him, and I shall do so to the end. I used to feel proud of my love, though it made me so wretched that I thought it would kill me. I am not proud of it any longer. It is a foolish poor-spirited weakness - as though my heart has only been half formed in the making. (366) 
There is a romantic reading to these words which no doubt might appeal to some of Trollope's readers, but there is also the self-recognition on Lily's part that this passion is just a commodity designed so that she may suffer comfortably. This is where I think that Trollope's emphasis lies since, as I have said, he loses no opportunity to indulge his heroine's suffering by taking her to London, out of her "little world". Here, certainly, the ambiguity as to the way in which we should understand the character remains: Lily is no fool, Crosbie is no conventional villain - actually one wonders whether he should be considered a "villain" at all-, Eames is too conventional to understand the exquisiteness of masochism, and most of the other characters are placidly installed in their role as members of a society which obliges a maiden girl to be married and have done with it. But, in spite of this, there are certain hints as to the real nature of the girl. Trollope, so to speak, proclaims Mrs Thorne (previously Miss Dunstable, one of the most interesting and intelligent characters in the books - as well as wealthy ${ }^{14}$ ) his speaker for the occasion, and in this role she admonishes Lily as to what her behaviour should be as regards her position in society:

[...] I think that a young woman ought to get married if the thing fairly comes in her way, and if her friends approve, and if she is fond of the man who is fond of her. It may be that some memory of what has gone before is allowed to stand in your way, and that it should not so be allowed. It sometimes happens that a horrid morbid sentiment will destroy a life. (628)

Lily's reluctance to succumb to this standard conception of love and marriage makes her what she is, but then throughout his opus Trollope does not seem to share her romantic vision of love. Love for Trollope is, in fact, more of an unavoidable and unromantic necessity which it is better to satisfy and so get through with it. (The possibility for social and economic conflict that any love story allows is a different matter entirely). If we add to this that in her speech Mrs Thorne hits the point when she talks about a "morbid sentiment", and that later on Lily's reflection on those words is presented in a way that does not strike us as convincing, then Trollope's position as to the real nature of his heroine seems quite clear. In this respect, Lily's thoughts are an example of the ability in Trollope's characters mentioned above not to tell themselves the whole truth (or not to tell themselves any truth at all):

There was nothing morbid in either her desires or her regrets. So she assured herself, with something very much like anger at the accusation made against her. She had been contented, and was contented, to live at home as her mother lived, asking for no excitement beyond that given by the daily routine of her duties. (629)

And it is hard to imagine anything more morbid than that. Moreover, this emphasis on her "something very much like anger" seems to suggest that she is forcing herself to be angry at such an accusation, as a way of reassuring herself in her convictions. But, despite this possible reading, Trollope arranges his story in a way that lets Lily Dale remain undisturbed in her position as a romantic heroine. So I am afraid that we will have to 
return once again to the author's commentaries on his character outside the frame of the novels themselves. Some years after writing the books, Trollope reminisces about Lily Dale in his Autobiography in the following way:

In the love with which she has been greeted, I have hardly joined with much enthusiasm, feeling that she is somewhat of a female prig. [...] It was because she could not get over her troubles that [readers] loved her.(117)

It would be too easy to dismiss such comment solely on the grounds of Trollope's supposed male chauvinism and adherence to the Victorian code. Trollope's readers, then, have usually loved Lily's tormented romanticism, whereas his view of her is quite different. But in the books Trollope plays the game of an unrelenting ambiguity so as to give his readers what they have always wanted a novel to be. He does not show all his cards, and so reveals himself as a more subtle writer than he is usually given credit for.

\section{III}

Trollope presents his characters either as individuals or as constituents of the dominant society of his time. Of course this is not just to say that they may be either protagonists or secondary characters. What I mean is that sometimes the events affecting their lives may be the result of their attitude as people who try to exert their right to be different, whether they are right or wrong. We have already studied Lily Dale as an instance of this. Mr Crawley, the leading male character in The Last Chronicle of Barset, is another one. Trollope considered him one of his best creations. Certainly his afflictions offered Trollope the opportunity to provide us with an in-depth analysis of the character's psychology. The accusation against him of having stolen some money is not interesting in itself, as Trollope well knew, since its resolution simply depends on the Arabins' absence from the country. But whereas today the mystery might have been solved by a mere call to a mobile phone, in the book it allows for a delay of hundreds of pages, so that Trollope may set his social machinery at work and, most importantly, it allows for a deeper delving into Mr Crawley's mind. The author's portrait of this man's mental instability, which leads him to doubt whether he really committed the crime, is brilliant indeed, but once again we may wonder how far we are supposed either to admire him in his individuality or to despise him as the outcast he ultimately is. But before concentrating on him, we might as well take a general view of the way in which Trollope defines his characters as parts of a whole.

As I have said, Trollope's characters are marked by their belonging to their society. And in a society ruled by economic principles mainly, they think and react in such terms. What we usually get in the description of a person is his position in society and the way in which he is accordingly regarded by others. Characters, therefore, do not exist by themselves, as individual human beings, but through their social and economic relationships with their equals. And this applies not only to those characters with a definite comic or satirical function, but to virtually all of them, no matter what their role in the 
books may be. Right at the beginning of The Last Chronicle of Barset, we are introduced to the lawyer Mr Walker in a very specific way:

Walker and Winthrop was the name of the firm, and they were respectable people, who did all the solicitor's business that had to be done in that part of Barsetshire on behalf of the Crown, were employed on the local business of the Duke of Omnium who is great in those parts, and altogether held their heads up high, as provincial lawyers often do.

Who is really producing this hurried enumeration of professional success, Trollope's narrator or any gossiper sitting at tea? And when Mr Walker first enters a few lines later, the customary physical description of the character immediately reverts to the same trend:

He was a man between fifty and sixty years of age, with grey hair, rather short, and somewhat corpulent, but still gifted with that amount of personal comeliness which comfortable position and the respect of others will generally seem to give. A man rarely carries himself meanly, whom the world holds high in esteem. (33)

So I would dare say that Mr Walker is not a person but a successful lawyer, and if Trollope only presents this aspect of the man it is not necessarily because he thinks that this professional prosperity is the most important thing in an individual. It is his characters who value merit in this way, though such merit does not really depend on the individual's ability, but on the esteem which he or she receives from the world, no matter whether it is deserved or not. It is appearances, connections and class values that really count. This description of Mr Walker can be understood either literally or ironically, though the narrator's comments seem to reinforce the second prospect. In other cases the possible disparity between reality and appearances is brought out more clearly. Another character in the same book, Miss Prettyman the elder, both runs a school for girls and keeps up an air of mistery and superiority which really becomes her in her neighbours' eyes. Once again we are not given her real self, but other people's idea of her, and that seems to be more than enough in order to exist properly in that world:

[...] perhaps it may be inferred that some portion of her great character for virtue may have been due to the fact that nobody ever saw her out of her own house. She could not even go to church, because the open air brought on neuralgia. She was therefore perhaps taken to be magnificent, partly because she was unknown.(72)

All these "perhaps" and "partly" are Trollope's recognition of the fact that it is usually quite risky to state things openly without any trace of reasonable doubt (again the fear of satirical excesses in him), but they can also be attributed to his habitual attitude of selfrestraint. He treats most of his characters with an excess of benignity in order to run away from his "un-Trollopian" side, so to speak, and this may account for his at times somewhat contradictory description of them and their mental processes, when he tries to justify their behaviour or qualify their actions. This explains the great number of "buts" we can find in such descriptions, the result, once again, of Trollope's attempt to create round characters 
who, at the same time, fit his readers' taste.

If material affluence, or the lack of it, is the most important element which defines a person's existence, then the main social group in the series, Trollope's clergymen, are no exception to the rule. They behave like squires (take Archdeacon Grantly), or like people aspiring to be promoted in their trade for the material benefits it may bring, rather than like spiritual workers. Even the pivotal figure of ethical reference in the whole series, $\mathrm{Mr}$ Harding, is subject in the first novel, The Warden, to a controversy which springs from the improper use of a fund, a controversy which is finally solved to everyone's satisfaction while the ex-warden's faith remains unmoved (which is not in the least surprising, since Trollope usually takes good care not to question or even deal with his churchmen's moral principles, and this omission already implies his vision of this very particular breed of men $)^{16}$. And we might as well add here, as some scholars have pointed out, that if $\mathrm{Mr}$ Harding represents the proper pattern of behaviour, and even survival, in his society, then once again Trollope is not presenting us with a great hero: Mr Harding is mild, honest and lovable, a refined Parson Adams who will not solve problems by resorting to blows but will play his cello instead with no intention of solving anything at all. He is essentially a passive character with little to say or do. And even his death in The Last Chronicle of Barset, in all its melancholy and serenity, is Trollope at his most sentimental, uninteresting and obvious, while Mrs Proudie's, on the contrary, reveals more of the acute novelist not the satirist - in him, when her corpse is discovered in bed, rigid and with her eyes wide open: a perfect final definition for the character.

Mark Robarts is another cleric who is given an external rather than an internal presentation, in spite of his position as the protagonist of Framley Parsonage. And this is not a mere satirical device but the best approach to the character: Trollope seems to be stating indirectly that there is little real substance in Robarts, and anything that happens to him will be in direct relation to his feeble inner self. We never actually get to know the real Robarts, simply because there is not much to know. He is yet another victim of the society in which he lives, and Trollope seems to be implying, by his customary disguised pessimism, that it is thanks to his submissiveness that Robarts manages to survive and occupy a stable position in it. It is not just that he takes a false step and nearly succumbs to the promises of opulence coming from one faction of his environment, but also that he finds salvation in the tyranny of his benefactress, Lady Lufton. (Cockshut summarizes Robart's dependence and vacuity very well when he states that "it is as if he recognized Lady Lufton as the legitimate keeper of his conscience"17). In the middle, as I said, there is really little to be learnt about his real nature, and thus, when he finally emerges as a prosperous and average Victorian gentleman who happens to work as a cleric and who has learnt to avoid material temptations, we realize that Trollope has been telling us two opposite stories at the same time. The story of Robarts is not the story of a common hero on his stumbling way to maturity, but the story of a fool. Meanwhile, Trollope has tried once again to hide his real view of his character and provide Robarts with the status and intricacies a protagonist is supposed to have, even though he makes it sufficiently clear from the very beginning, with his customary and misleading irony, that Robarts is simply what his society wants him to be: 
But little has as yet been said, personally, as to our hero himself, and perhaps it may not be necessary to say much. Let us hope that by degrees he may come forth upon the canvas, showing to the beholder the nature of the man inwardly and outwardly. Here it may suffice to say that he was no born heaven's cherub, neither was he a born fallen devil's spirit. Such as his training made him, such he was. ${ }^{18}$

So "our hero" is essentially dull and grey, and our un-Trollopian Trollope has given us another un-heroic hero. But it is this very prosaic quality in Robarts that enables him to appear again in The Last Chronicle of Barset as an active member of the social forces of Barset who immediately run to the defence of $\mathrm{Mr}$ Crawley when he is accused of theft. Crawley is a gentleman, one of them, and thus can be no thief. Certainly Robarts is better suited to this unindividualistic secondary role. In it, he simply has to comply with a number of social and ethical rules and continue with his placid existence as one more component of the Greek chorus. (I have not chosen this term by mere chance: witness how Trollope goes to pains to make most of his characters comment on Mrs Proudie's death, in the usual detached style so typical of Trollope in such cases).

Mr Crawley, on the contrary, is a natural-born individual. It is no coincidence that it is he who admonishes Mark Robarts in Framley Parsonage as to his deviant lifestyle, as a strict member of the Church of England. But such convictions do not give us the impression that Trollope agrees with such high-minded people as Mr Crawley. And now, in The Last Chronicle of Barset, we are forced again to decide what Trollope's opinion of his character is, since he is given a leading role. The initial problem is that Mr Crawley is a gentleman, a scholar and a respected cleric, but he also happens to be poor. This economic inconvenience partly determines his individualistic attitude towards the world. Mr Crawley feels frustrated because his merits have not been materially rewarded as they deserve to be, and so isolates himself into his world of duty and study, even if this mean unhappiness for his wife and daughters. This isolation gradually increases his sense of intellectual superiority and precipitates his fall. But the difference here, as with Lily Dale, is that it is not exactly the external forces of society who are to be held responsible for a situation like Mr Crawley's. He may be the victim of an uneven system of retributions as far as certain clerics are concerned, but he is basically a victim of his own ego. Here Trollope is not simply interested in presenting a man with certain social problems, but the real nature of a man in mental trouble who considers himself different from the rest. The Barsetshire world that Trollope presents us with is not one of a bucolic, placid, easy life but one of social relationships regulated or managed from certain centres of influence and power. Characters like Mark Robarts who succumb to their legislation (whether Mrs Proudie's or Archdeacon Grantly's or Lady Lufton's or whoever's) succeed, while those who isolate themselves in small houses at Allington or at Hogglestock vicarage (Crawley's home) are also to some extent excluding themselves from any kind of social success.

In the case of Mr Crawley, Trollope is once again ambiguous as to his character's status. What kind of hero is he supposed to be? A romantic, tormented, misunderstood person with strong convictions and a great capacity for endurance who suffers an unjust situation, or a prig who suffers from a superiority complex? In the long run the idea we get of him is that he is a combination of both, but again Trollope modulates his presentation 
of the character so as not to fall too heavily on either side. It has often been said that $\mathrm{Mr}$ Crawley rises to tragic status. Certainly his story is sombre and far more serious than that of Mrs Dobbs Broughton, the wife of the London merchant who goes bankrupt while she leads a romantic life of delusion ruled by empty clichés, but we should remember that $\mathrm{Mr}$ Crawley's life is also a delusion after all. Mr Crawley is not just a man of high principles and learning, but a selfish man who, because of those very qualities, believes himself to be superior, and thus is responsible for his own fall ${ }^{19}$. The problem is that the world at large surrounding him does not act according to perfect or absolute principles either, as we have already seen, and so cannot be taken as a solid point of reference. Mr Crawley may be wrong in certain points, but so are most people. As Mrs Crawley well knows, in their world of opposed extremes and misleading appearances, her husband's peculiarities are liable to be misunderstood:

His wife knew well that he was not mad; but yet she knew that there were dark moments with him, in which his mind was so much astray that he could not justly be called to account as to what he might remember and what he might forget. How would it be possible to explain all this to a judge and jury, so that they might neither say that he was dishonest, nor yet that he was mad? (64)

Mr Crawley is a tragic figure because he is depicted fully in the round in all his inconsistencies, in all those little details that make up a person, no matter whether they are assumed to be positive or negative ones. We see him indulging in self-pity himself and resenting the world around him from an irrational, proud and selfish point of view; we see him giving Biblical overtones to his misfortunes, something that suits the character perfectly ("My poor child! my darling! She has found grace in this man's sight; but even of that has her father robbed her! The Lord has visited upon the children the sins of the father, and will do so to the third and fourth generation.", 683); we even find Trollope's narrator giving us a direct and unambiguous account of the man's defects ("He pitied himself with a commiseration that was sickly in spite of its truth. It was the fault of the man that he was imbued too strongly with self-consciousness. [...] It was not sufficient for him to remember that he knew Hebrew, but he must remember also that the dean did not.", 650). But we also see him on the way to the bishop's palace while relishing his possible victory over the bishop and Mrs Proudie in a very human - and even childish - way, and, most of all, we see him doubting of his own sanity and being totally aware of his faults ("She knew that he was almost a saint, and yet almost a castaway through vanity and hatred of those above him. But she did not know that he knew all this of himself also.", 414).

So, with Mr Crawley, Trollope knows that he does not like this kind of man, but he also knows that the society he is depicting is too imperfect in its moral basis, and consequently $\mathrm{Mr}$ Crawley is not to receive too strict a condemnation. Or perhaps he does. Maybe there is a final irony in the fact that the love story between Mr Crawley's daughter and Major Grantly is resolved satisfactorily (as are all conventional love stories in the series), and so Mr Crawley is condemned to co-exist on amiable terms with such a 
different character as Archdeacon Grantly. Sometimes the price to be paid for material welfare is too heavy.

As David Skilton tells us, throughout Trollope's career there were "ever-growing complaints that truth alone is not enough, and that some 'elevation' or 'idealization' of subject-matter is essential", on the part of most of his contemporary reviewers ${ }^{20}$. He was equally accused of "sordid realism and the misrepresentation of moral institutions, [...] of moral irresponsibility [...] in writing about a morally bankrupt society without providing an idealized solution to its problems." ${ }^{21}$ This is especially to be applied to his later novels, but this view of the world is already present in the Barsetshire novels. And what was meant as criticism happens partly to be a very accurate definition of Trollope's books, if we invert its negative original meaning. If Trollope does not provide any of those positive solutions his contemporaries expected, it is simply because he does not know any. He merely subscribes to that negative view of the human condition that the most eminent Augustan writers of the preceding century such as Swift or the Pope of the Moral Essays had so keenly depicted. ${ }^{22}$

The Barsetshire world can be read as a nostalgic picture of a traditional; rural England with comic and mildly satirical overtones (and even today it is much more profitable to sell a novel under the attractive label of being first and foremost "comic"). We certainly find this amusing attitude in certain episodes such as the "Ullathorne sports" in Barchester Towers, where Trollope experiments with the mock-epic as a proper means of laughing at the ambition to recreate Saxon traditions in modern times. (Where exactly is Trollope's sense of "Englishness" then?). But, as I have said, Trollope's realism is a disguise for his real views. The Barsetshire world is based on an alienating system of forces which can be just as dangerous and uneven as the modern world London seems either to promise or to threaten with. But it is Trollope's main device to tell his stories in a way that allows for different readings, and this also accounts for the many contradictions in the man himself. As Cockshut puts it, "in the novels he appears as a moderate man, making excuses for everyone, and always keeping the middle of the road." ${ }^{23}$ This is Trollope's way of a) making his readers believe that he fully adheres to the social and ethical code in place at that time, b) acknowledging the difficulty of stating exact polar views of people, and, most importantly, c) avoiding or hiding his "un-Trollopian" side, which would have forced him to give a far more pessimistic view of his main characters, of whom he boasted that he lived with them to the extent that they even had an unpredictable life of their own. Any attempt at "sublimity" or "elevation" in his contradictory rendering of common life would have meant a distorted vision of "the way they lived then". Meanwhile, Mrs Proudie, Lily Dale and Mr Crawley still survive, awaiting those who may delight in them as grotesque figures, tormented romantic heroines, or social victims. 


\section{Notes}

1. Although in Trollope's case we cannot forget that he quite often plays at breaking such expectations by anticipating how things are going to be solved, thus destroying any possibility of interest on the reader's side as far as the dénouement of the plot is concerned. A remarkable example of this peculiar working method in the series we are dealing with can be found in Doctor Thorne (1858), where the narrator hardly wastes any time in giving us the answer to the main conflict operating in the story: Will Frank Gresham and Thorne's niece, Mary, overcome the opposition of Frank's family and finally get married? Very early in the narrating we guess that the answer is in the affirmative, since Trollope thoroughly destroys almost all possibilities of intrigue either by making things too clear or by anticipating facts which other writers would exploit to a greater degree. There is an element of imperfection on Trollope's side as far as his technique is concerned, as Stephen Wall explains: 'The outcome of the story is visible early on, and it is hard not to feel that by the third volume Trollope has been driven to delaying tactics in order to keep the novel going until the allotted space is filled." (Trollope and Character, London: Faber and Faber, 1988, 35) Nevertheless, this Trollopian practice, the main objective of which was to avoid any of the sensational trends that were so much in vogue at the time, may bring about a different kind of problem. In Doctor Thorne the fact that Frank and Mary marry entails that previously she is going to inherit the fortune left by her other uncle, Sir Roger Scatcherd, and at the same time this implies that the author is from the very outset of his story forced to kill both Sir Roger and his legal heir, his son Louis, so as to be able to reach the solution which he has already announced beforehand. In this way, the artificiality of any realistic novel is too clearly exposed, and Trollope's aim of avoiding any sensational peccadillo is oddly thwarted. Be this as it may, we might point out here that the Scatcherds are two very interesting characters with a highly Dickensian profile. Their compulsive alcoholism and almost primeval and existential angst is the means through which Trollope sends them to their necessary death, but, on the way, their refusal to give up their consuming habit makes them good examples of the human being's inability to refrain from certain low passions, and meanwhile it is quite hard to perceive an explicit condemnation - or at least a convincing one - of their behaviour on the author's side. Furthermore, the case of Scatcherd senior is particularly interesting, since it allows for other readings. The son drinks merely out of his weakness as a human being, but the father finds in alcohol an outlet to his difficult position in society. He is a man from humble origins who has made a fortune and gained official social recognition. Good as this may sound, the truth is that Scatcherd is an extreme type of the social outcast. Once he has made lots of money, there is nothing else for him to do:

"Habit is second nature, man; and a stronger nature than the first. And why should I not drink? What else has the world given me for all that I have done for it? What other resource have I? What other gratification?" (Oxford: Oxford World's Classics, 1980, 138-39)

Coming from such a materialistic writer as Trollope is supposed to be, these sentences may appear as a surprise in their denial of the comfort that money affords. But Trollope is simply indicating in his usual oblique style that society has many different ways of destroying those of its members who do not fit into its regulated uniformity.

2. Allen, W, The English Novel (London: Penguin, 1991, 1st ed. 1954), 199-200.

3. Early in his career he adopted the practice of writing a certain number of words every day, and he went as far as to keep an account of the realization of his daily task in his diary. 
4.It must have been the combination of these limitations expressed by Allen and these interpretation problems that made C.P.Snow write of Trollope that "[...] of all writers, he is the one least adapted for most kinds of academic approach." ("Trollope: The Psychological Stream", in Benedikz, B.S (ed), On the Novel, London: Dent, 1971, 3).

5. Anthony Trollope: A Critical Study, New York: New York U.P., 1968 (1st.ed. 1955), p. 9. I should also acknowledge Stephen Wall's contribution in his Trollope and Character, where he makes a brilliant analysis of the main characters in the series. However, Wall sometimes falls short -in a very Trollopian way - of going further in his dissection of the character's real motivations.

6. For a broad discussion of the basic moral codes ruling Victorian behaviour, see Nardin, J, Trollope and Victorian Moral Philosophy (Athens: Ohio University Press, 1996).

7. An Autobiography (London: Penguin, 1996), p.177.

8. No matter how often Trollope's narrator may state that she has a heart, Mrs Proudie constantly behaves like a fatuous ogre who would fit into any cave of spleen. Let us take as a rule not to trust Trollope's narrative voice.

9. Writing about his "Palliser" novels, Trollope states that "if I write politics for my own sake, I must put in love and intrigue, social incidents with perhaps a dash of sport, for the sake of my readers." (An Autobiography, 201-202).

10. London: Penguin, 1986, p.248.

11. "The depth and the breadth and the narrowness and the shallowness of each should be clear to him [the novelist]. And as, here in our outer world, we know that men and women change, -become worse or better as temptation or conscience may guide them-, so should these creatures of his change, and every change should be noted by him". (An Autobiography, 150)

12. London: Penguin, 1991, 21.

13. Her popularity was such at the time of the publication of the novels that two ships were named after her, as David Skilton reminds us in Anthony Trollope and His Contemporaries (London: Macmillan, 1996, 2nd ed., 20). Some contemporary critics have continued to take Lily for the heroine she is supposed to be, and have put all the blame on Crosbie's side when, due to his social interests, he jilts her: "Lily is heartbroken. Trollope has rarely been better than with this study of desperate grief borne with desperate courage. It is painful to read."(Hansford Johnson, P, “Trollope's Young Women", in Benedikz (ed), op.cit., 24). Equally, the supposedly Trollopian tendency not to let his jilted heroines get finally married to another man has also often been misunderstood. I do not think that this Victorian cliché was really of much interest to Trollope (it certainly is to Lily, since, as she herself explains, she even kissed Crosbie and thus gave herself to him!). He was rather interested in some of his character's capacity for obstinacy and self-deceit, and Lily Dale is a good example of this. And then, to add more fuel to the ambiguity, when Johnny Eames the conventional avenger hits Crosbie, or when the latter's marriage proves to be a total failure, we might wonder how far Trollope punishes his character mainly for his readers' sake and pleasure, which could indicate a disguised Trollopian irony regarding such hunger for honorable revenge both in his society at large and in his readers in particular.

14. So it is not surprising that Trollope rewards the rectitude and typical Victorian stubbornness of Dr Thorne in the novel of the same title by marrying him to her and her money in Framley Parsonage. However, Miss Dunstable is another good example of the disparity between reality and appearances. What the "materialistic" Trollope tells us through her is that wealth can be a terrible burden, since Miss Dunstable knows only too well that she is condemned to be regarded by everybody else as just the owner of a great fortune. So money does not always bring happiness, another apparent contradiction in Trollope's thought. 
15. Trollope showed far more respect and admiration for his leading female character in Framley Parsonage, Lucy Robarts, whom he defined in the Autobiography as "the most natural English girl that I ever drew" (95). Lucy knows how to play her (honest) cards, satisfy everyone and thus become Lady Lufton: here female submissiveness wins. So much for Trollope's concept of what a "natural" girl is. But, at the same time, she does not usually deceive herself in Lily Dale's style, but, on the contrary, is capable of resorting to self-irony in her moments of greatest despair, to her sister-in-law's - a much more conventional woman - confusion, since she does not know when to take Lucy seriously. Perhaps Lucy's genuineness comes then from her ability to distinguish between appearances and real self.

16. As Cockshut says, "most of Trollope's clergy have little concern with religion". (op.cit., 67) But this does not necessarily mean that Trollope openly critizises his clerics for their lack of sainthood. They are simply men in a society and, as such, nothing else might be expected: "Trollope's view that worldliness is normal and not necessarily something to be ashamed of means that when he shows clergymen with their minds on earthly things he registers the inconsistency but does not appear to be catching them out [...]." (Wall, op.cit., 42). Thus even Mr Harding in his passivity appears all the more real than, for instance, Margaret's father in Elizabeth Gaskell's North and South.

17. op.cit., 69.

18. Framley Parsonage, London: Penguin Classics, 1986, 37.

19. Although, as is usually the case with Trollope, there is another side to Crawley's alleged intellectual superiority, as Elizabeth R. Epperly says: "It is hard to begrudge Crawley his intellectual vanity when it is the only weapon he has against the pressures of the diocese. As long as he can pride himself on his scholastic powers, he can hold up his head among his more fortunate fellow clergymen." (Patterns of Repetition in Trollope, Washington D.C.: The Catholic University of America Press, 1989, 54) But even so this is to consider Mr Crawley mainly as a victim to outer forces, forgetting or dismissing the other side of the question. We should remember that, as one of Trollope's many biographers of late tells us, "the idea of obsessional grievance as an occupation for life was to pervade Anthony's novels." (Victoria Glendinning, Trollope, London: Pimlico, 1993, 1st ed. 1992, 12).

20. Skilton, op.cit., 10.

21. ibid., 31-32.

22. Or even Samuel Johnson, with whom Trollope shared a tendency towards melancholy: "As I know more of mankind I expect less of them, and am ready now to call a man a good man, upon easier terms than I was formerly." ( Boswell, J, The Life of Johnson, Harmondsworth: Penguin, 1979, 307).

23. op.cit., 21. 